\title{
INFLUENCE OF LIME AND FERTILIZERS UPON THE MINERALIZATION OF PEAT NITROGEN IN INCUBATION EXPERIMENTS
}

\author{
By \\ Armi Kaila, Sylvi Soini, and Erkki Kivinen \\ University of Helsinki, Department of Agricultural Chemistry, Helsinki. \\ Received 25th January 1954.
}

The vast areas of peat soils in North Finland contain large amounts of nitrogen which could support an intensive crop production, if only its mobilization occurred rapidly enough. The fact that this is not the case has been explained to be due to the coolness of the rather short summer in these regions. Yet, there may be some possibilities to increase the speed of the mineralization of the organic nitrogen compounds in the peat soils, for example by treatment with sand in order to improve the temperature conditions, or by the application of lime and fertilizers to stimulate the microbial activity in soil. The effectiveness of such procedure can of course be estimated only by field experiments, but some valuable trends may also be found by laboratory studies.

In laboratory experiments in which the peat samples are incubated with various applications, generally, the speed of the reactions is far higher than under natural conditions. The uptake of nutrients by plants is excluded as well the washing down of soluble compounds. Drying of samples, even if performed at room temperature, can alter the quality of peat colloids, and the pulverization of the peats necessary for the homogeneity of the material makes the conditions even more unnatural. The microtlora that develops under these conditions may largely differ from the native one. Consequently, experiments of this kind seem to be able to give only a few results directly applicable to practice. The most valuable information that can be obtained concerns differences between various kinds of peat, e.g. in the microbial immobilization and mineralization of nitrogen regulated by the presence of available carbon compounds.

These facts were taken into consideration when series of incubation experiments were carried out in the laboratory with eight samples of typical peats collected from North Finland. Differences in the changes in their mineral nitrogen content under various conditions were examined. In the present paper results from the first experi- 
mental series are reported dealing with the effect of lime, and phosphorus, potassium, and nitrogen fertilizers as well as of wood ash and some trace elements upon the peat nitrogen.

\section{Peat samples}

Four of the peat samples used in the experiments were fen prats and represented tillable swamps (virgin productivity 5-10). The other four samples were Sphagnum peats from oligotrophic bogs (virgin productivity 1-4). All the samples were taken from the surface layers of virgin peat lands, and their degree of decomposition was rather low. The following list gives more detailed information of the characteristics of the fens and bogs.

Sample 1. Sphagnum-Carex peat (SCp) from a mesotrophic waterlogged treeless Carex-bog in Rovaniemi. In the hollows of the bog the surface vegetation chiefly consisted of Carex magellanica and Menyanthes trifoliata with a few individuals of Carex lasiocarpa, Carex chordorrhiza and Equisetum fluviatile. Some hummocks of Sphagnum papillosum and Sphagnum magellanicum with edges containing mesotrophic species were present. The virgin productivity was 6 .

Sample 2. Wood-Carex peat (LCP) from a wooded swamp with herbs and grasses in Tervola. The moss vegetation was formed of Sphagnum recurvum coll., Sphagnum squarrosum, and Mnium sp. Carex magellanica, Menyanthes trifoliata, and Comarum palustre were present in abundance, Calamagrostis purpurea, Filipendula ulmaria, and Salix lapponica in lower numbers. The virgin productivity was 7 .

Sample 3. Bryales-Carex peat $(\mathrm{BC})$ from a Scorpidium fen in Alatornio. In the surface vegetation Scorpidium scorpioides predominated, of the Carex species, Carex livida may be mentioned. The virgin productivity corresponded to the class 7 .

Sample 4. Eutrophic Sphagnum-Carex peat (EuSCp) from a birch fen in Tervola. The surface vegetation consisted of Sphagnum Warnstorfianum, Paludella squarrosa, Aulacomnium palustre, Tomenthypnum nitens, Carex dioeca, Scirpus Hudsonianus, Equisetum fluviatile, Eriophorum polystachyum, Menyanthes trifoliata, Saxifraga hirculus, and other herbs and grasses. The virgin productivity was 8 .

Sample 5. Sphagnum peat (Sp) from a Sphagnum fuscum pine bog in Rovaniemi. Sphagnum fuscum formed the largest part of the surface vegetation. The presence of Carex globularis in rather high numbers indicated that the peat soil properly was a Carex globularis bog invaded by Sphagnum fuscum. Empetrum nigrum, Vaccinium uliginosum, Betula nana, Ledum palustre, and Andromeda polifolia were also present. The virgin productivity was 1 .

Sample 6. Carex-Sphagnum peat (CSp) from a Scirpus caespitosus-Sphagnum papillosum treeless bog. In addition to Sphagnum papillosum and Scirpus caespitosus the surface vegetation contained Sphagnum cuspidatum, Menyanthes trifoliata, and some individuals of Carex limosa, Carex rostrata, Eviophorum polystachyum, and Molinia coerulea. The virgin productivity was 2 .

Sample 7. Wood Carex-Sphagnum peat (LCSp) from a Eviophorum vaginatum-Carex pine bog in Rovaniemi. The surface vegetation was formed by Sphagnum recurvum coll., Sphagnum Russowii, Eriophorum vaginatum, Carex lasiocarpa, Menyanthes trifoliata, and subshrubs characteristic of pine bog vegetation. The virgin productivity was $2-3$.

Sample 8. Carex-Sphagnum peat (CSp) from a Carex rostrata bog in Rovaniemi. In addition to Sphagnum recurvum coll., Sphagnum papillosum, and Carex rostrata, and lower numbers of Carex lasiocarpa, Carex chordorrhiza, Menyanthes trifoliata, and Andromeda polifolia were present. The virgin productivity corresponded to the class 3 .

Some chemical and physical data for the peat samples are collected in the following tables. According to the figures in Table 1 no marked limits existed between the characteristics of the groups of fen peats (samples 1-4) and Sphagnum peats (samples 6-8). Only the very slightly decomposed Sphagnum fuscum peat number 
Table 1. Some characteristics of the peat samples

\begin{tabular}{|c|c|c|c|c|c|c|c|c|}
\hline $\mathrm{Sam}_{1}$ & $\begin{array}{c}\text { Degree of } \\
\text { decom- } \\
\text { position }^{1}\end{array}$ & $\begin{array}{c}\text { Weight } \\
\text { of } \\
\text { volume }\end{array}$ & $\begin{array}{c}\text { Total } \\
\text { water- } \\
\text { holding } \\
\text { capacity } \\
\%\end{array}$ & $\mathrm{pH}_{\mathrm{H}_{2} \mathrm{O}}$ & $\mathrm{pH}_{\mathrm{KCl}}$ & $\begin{array}{c}\text { Ash } \\
\%\end{array}$ & $\begin{array}{c}\text { Total } \\
\mathrm{N} \\
\%\end{array}$ & $\begin{array}{c}\text { Total } \\
\mathrm{P} \\
\%\end{array}$ \\
\hline $\mathrm{SC}_{\mathrm{p}}$ & $\ldots \quad \mathrm{H}_{4}$ & 0.26 & 500 & 4.68 & 3.68 & 4.1 & 3.24 & 0.11 \\
\hline $\mathrm{LC}_{\mathrm{p}}$ & $\ldots \ldots \ldots \ldots \quad \mathrm{H}_{3-4}$ & 0.28 & 370 & 4.92 & 4.21 & 6.7 & 3.16 & 0.13 \\
\hline BCp. . & $\ldots \ldots \ldots \cdots \quad \mathrm{H}_{2-3}$ & 0.21 & 650 & 4.73 & 4.00 & 4.7 & 3.16 & 0.05 \\
\hline EuScp & $\ldots \ldots \ldots \quad \mathrm{H}_{3}$ & 0.21 & 670 & 5.60 & 5.24 & 7.2 & 2.21 & 0.09 \\
\hline Sp $\ldots$ & $\ldots \ldots \ldots \ldots \quad \mathrm{H}_{1}$ & 0.10 & 880 & 3.99 & 3.20 & 10.7 & 1.24 & 0.07 \\
\hline CSp & $\ldots \ldots \ldots \ldots \quad \mathrm{H}_{3}$ & 0.27 & 380 & 4.72 & 3.73 & 7.8 & 2.99 & 0.08 \\
\hline LCSp & $\ldots \ldots \ldots \ldots \quad \mathrm{H}_{4}$ & 0.27 & 380 & 4.54 & 3.82 & 7.5 & 2.47 & 0.12 \\
\hline $\operatorname{CSp}$ & $\ldots \ldots \ldots \ldots \quad \mathrm{H}_{4}$ & 0.29 & 450 & 4.52 & 3.72 & 11.7 & 2.74 & 0.14 \\
\hline
\end{tabular}

3 v. Post (4)

5 differred from all the other samples. On the average, the $\mathrm{pH}$-values and the total nitrogen content of the fen peats tended to be higher than those of the Sphagnum peats, but in the phosphorus content and in the ash content no such superiority of the fen peats could be noticed.

The chemical composition of the peat samples were analyzed by the proximate method of WAKSMAn, modified by SPRINGER (5). These results are reported in Table 2. Even according to these data the differences between the various peats were not very marked, and probably originated from the various degree of decomposition more than from the kind of peat. Probably in well humified samples the differences between the cellulose and hemicellulose contents of fen peats and Sphagnum-peats would have been more distinct (cf. 3,6) than in these rather slightly decomposed samples. The grades of humification estimated by eye and reported in Table 1, agreed fairly well with the picture given by the values in Table 2 . The high content of acid soluble material in the sample 5 was in accordance with its very low degree of decomposition. Also the third sample with a $\mathrm{H}$-grade of $2-3$

Table 2. Fractions of organic matter in the peat samples

(Expressed as a percentage of dry matter)

\begin{tabular}{|c|c|c|c|c|c|c|c|c|}
\hline Fraction & $\begin{array}{c}1 . \\
\text { SCp }\end{array}$ & $\begin{array}{c}2 . \\
\mathrm{LC} p\end{array}$ & $\begin{array}{c}3 . \\
\mathrm{BC} \mathrm{p}\end{array}$ & $\begin{array}{c}4 . \\
\text { EuSCp }\end{array}$ & $\begin{array}{c}5 . \\
\text { Sp }\end{array}$ & $\begin{array}{c}6 . \\
\mathrm{CSp}\end{array}$ & $\begin{array}{c}7 . \\
\text { LCSp }\end{array}$ & $\begin{array}{c}8 . \\
\mathrm{CSp}\end{array}$ \\
\hline Ether-soluble ........ & 6.3 & 4.2 & 3.5 & 1.1 & 3.0 & 4.0 & 9.5 & 6.3 \\
\hline Ethanol-soluble ...... & 3.1 & 2.2 & 2.2 & 2.2 & 1.6 & 2.1 & 2.8 & 2.2 \\
\hline Water-soluble $\ldots \ldots$. & 2.9 & 3.5 & 2.0 & 2.7 & 3.2 & 2.5 & 2.8 & 3.0 \\
\hline HCl-soluble material . . & 25.2 & 28.7 & 26.2 & 29.6 & 43.7 & 27.4 & 26.6 & 29.7 \\
\hline "Hemicelluloses». ... . & 11.8 & 10.1 & 13.3 & 12.6 & 14.5 & 12.9 & 9.2 & 10.3 \\
\hline $\mathrm{H}_{2} \mathrm{SO}_{4}$-soluble material & 14.0 & 17.6 & 25.0 & 19.8 & 25.4 & 17.1 & 11.7 & 14.6 \\
\hline Cellulose & 6.5 & 7.3 & 13.8 & 11.4 & 17.3 & 9.4 & 4.6 & 6.3 \\
\hline Insoluble material .... & 45.7 & 41.8 & 38.6 & 41.2 & 31.3 & 46.0 & 46.0 & 42.9 \\
\hline "Lignins" . . . . . . . & 37.6 & 34.2 & 29.9 & 36.0 & 20.3 & 34.9 & 39.4 & 32.5 \\
\hline "Crude protein" ...... & 19.4 & 18.7 & 19.2 & 13.2 & 7.2 & 13.7 & 14.8 & 16.5 \\
\hline
\end{tabular}


Table 3. Fractions of nitrogen in the peat samples (Expressed as a percentage of total nitrogen)

\begin{tabular}{|c|c|c|c|c|c|c|c|c|}
\hline Fraction & $\begin{array}{c}1 . \\
\mathrm{SCp}\end{array}$ & $\begin{array}{c}2 . \\
\mathrm{LC} p\end{array}$ & $\begin{array}{c}3 . \\
\mathrm{BCp}\end{array}$ & $\begin{array}{c}4 . \\
\text { EuSCp }\end{array}$ & $\begin{array}{c}5 . \\
\text { Sp }\end{array}$ & $\begin{array}{c}6 . \\
\text { CSp }\end{array}$ & $\begin{array}{c}7 . \\
\text { LCSp }\end{array}$ & $\begin{array}{r}8 . \\
\operatorname{Csp}\end{array}$ \\
\hline Ether-soluble ....... & 2.5 & 2.0 & 2.0 & 3.0 & 5.0 & 2.0 & 3.0 & 2.5 \\
\hline Ethanol-soluble ...... & 2.5 & 2.0 & 3.0 & 3.5 & 5.5 & 2.0 & 3.0 & 1.5 \\
\hline Water-soluble & 4.5 & 5.0 & 3.0 & 4.5 & 8.0 & 4.0 & 5.0 & 4.5 \\
\hline Acid-soluble $\ldots \ldots \ldots$ & 63.5 & 78.0 & 78.0 & 57.0 & 59.5 & 70.0 & 66.0 & 69.0 \\
\hline Insoluble $\quad \ldots \ldots \ldots \ldots$ & 27.0 & 13.0 & 14.0 & 32.0 & 22.0 & 22.0 & 23.0 & 23.5 \\
\hline
\end{tabular}

contained cellulose and hemicellulose more than the other samples showing higher $\mathrm{H}$-grades. The amounts of the insoluble material and lignins were the higher the lower the contents of acid soluble compounds or the higher the degree of decomposition.

Table 3 which contains data for the fractionation of nitrogen compounds by the WAKSMAN procedure reveals that from about 60 to 80 per cent of the total nitrogen in the peat samples was acid-soluble. Probably a large part of this nitrogen was dissolved already by diluted hydrochloric acid as in the analyses reported by WAKsman and Stevens (6), Wilson and Staker (7), Kivinen (3), and Fraser (1). No clear correlation between the relative amounts of insoluble nitrogen and of insoluble material in general, can be stated. Now, the fact must be taken into consideration that the proximate method employed is not the best one for the fractionation of nitrogen compounds in organic material.

According to the results reported above, these rather slightly humified peat samples did not show as distinct differences in their chemical composition and characteristics as could have been expected on the basis of the quality of the peat lands from which they originated. Therefore, it was interesting to study what differences could be found in the mobilization of their nitrogen.

\section{Analytical methods}

Ammonium nitrogen: A 10 per cent solution of potassium chloride was employed for the extraction of $\mathrm{NH}_{4}$-nitrogen. The fresh $20 \mathrm{~g}$-samples were first shaken for one hour in $100 \mathrm{ml}$ of the solution, and after filtration washed twice with $25 \mathrm{ml}$ of the liquid. The ammonia in the extract was determined by distillation with MgO.

Nitrate-nitrogen: The fresh $20 \mathrm{~g}$-samples were shaken for 5 minutes in $100 \mathrm{ml}$ of saturated calcium sulphate solution, and nitrate nitrogen estimated in an aliquot of the filtrate by the phenol-disulphonic acid method using an EEL-photoelectric colorimeter.

Nitrite-nitrogen: The presence of nitrite nitrogen was estimated on the basis of the intensity of the red colour produced by the GRIESs reagents in the calcium sulphate extracts.

\section{Plan of the experiments}

In all the experiments air-dried ground peat samples were used. Incubation was carried out in glass pots holding one or three liters and loosely covered with plastic. The peat samples were moistened to 70 per cent of their total water-holding capacity. 
When calcium carbonate was applied it was mixed in the dry sample, in an amount capable to raise the $\mathrm{pH}$ value of the peat samples in water suspension to about $\mathrm{pH}$. The amounts of calcium carbonate added to $100 \mathrm{~g}$ of air-dry peat were: $2.4 \mathrm{~g}$ to sample 5. Sp; $1.4 \mathrm{~g}$ to samples 1 . SCp, 6. CSp, and 7. LCSp; $1.3 \mathrm{~g}$ to sample 8. CSp; $1.2 \mathrm{~g}$ to sample 3. BCp; $0.9 \mathrm{~g}$ to sample 2. LCp; $0.6 \mathrm{~g}$ to sample 4. EuSCp.

Potassium and phosphorus were applied as potassium phosphates in amounts equal to $1000 \mathrm{~kg}$ of 40 per cent potash fertilizers and to $2000 \mathrm{~kg}$ of superphosphate per hectare. Treatments with phosphorus were performed as diluted phosphoric acid, and an extra amount of calcium carbonate was added to neutralize the acid.

The pots which were treated with mineral nitrogen received it as ammonium nitrate. It was applied in an amount corresponding to $1000 \mathrm{~kg}$ of calcium nitrate per hectare.

Copper was given as copper sulphate, zinc as zinc chloride, and molybdenum as ammonium molybdate, in amounts equal to $50 \mathrm{ppm}$ of copper, zinc, or molybdenum. All these as well as the other fertilizers were applied in solutions mixed with the water used for the moistening of the samples.

In the first series the treatments were as follows:
1. 0
5. $\mathrm{Ca}$
2. $\mathrm{PK}$
6. $\mathrm{CaPK}$
3. $\mathrm{PKCu}$
7. $\mathrm{CaPKCu}$
4. $\mathrm{NPKCu}$
8. $\mathrm{CaNPKCv}$

The pots were incubated at room temperature $\left(15^{\circ}-22^{\circ} \mathrm{C}\right)$ for $8-10$ months.

The second experiment was carried out at lower temperatures in order to get nearer to the conditions in nature. This experiment was started in spring, and for the first months it could be held at about $11-13{ }^{\circ} \mathrm{C}$. Later in summer the temperature increased to $15^{\circ} \mathrm{C}$, and during the last two months of the half year of the incubation it again dropped to about $10^{\circ} \mathrm{C}$. The treatments in this experiments were:
1. 0
2. Ca
3. $\mathrm{CaP}$
4. $\mathrm{CaPK}$
5. CaPKN

In a concise experiment the effect of wood ash upon the mobilization of nitrogen in the sample 1. SCp was examined. The ash was applied in amounts corresponding to 2 and 10 tons per hectare. The neutralizing effect of $1000 \mathrm{~kg}$ of the ash was equal to $420 \mathrm{~kg}$ of calcium oxide, and it contained 1.7 per cent phosphorus, and 13.6 per cent of potassium. The treatments were as follows:
1. 0
2. Ash $2 \mathrm{t} / \mathrm{ha}$
3. Ash $10 /$ tha
4. $\mathrm{PK}+2$
5. $\mathrm{CaPK}+2$

In the first experiment with trace elements the treatments of the samples 4 . EuSCp and 8. CSp, in addition to PK, were as follows: $1.02 .1 / 2 \mathrm{Cu} \mathrm{3.} \mathrm{Cu} \mathrm{4.} 2 \mathrm{Cu} 5 . \mathrm{Zn} \mathrm{6.} \mathrm{Mo}$ 7. $1 / 2 \mathrm{Cu}+\mathrm{Zn}+\mathrm{Mo}$. The incubation period was three months, the temperature about $20^{\circ} \mathrm{C}$.

In the second experiment with the trace elements samples 2. LCp and 6. CSp were treated with $\mathrm{PK}$ and with $\mathrm{Cu}, \mathrm{Mo}$, and $\mathrm{Zn}$ in the following way: 

1. 0
6. $\mathrm{Ca}$
2. $\mathrm{Cu}$
7. $\mathrm{Ca} \mathrm{Cu}$
3. Mo
8. $\mathrm{Ca} \mathrm{Mo}$
4. $\mathrm{Zn}$
9. $\mathrm{Ca} \mathrm{Zn}$
5. $\mathrm{Cu}$ Mo $\mathrm{Zn}$
10. Ca Cu Mo $\mathrm{Zn}$

These pots were incubated at $7-11{ }^{\circ} \mathrm{C}$ for three months.

In the trace element experiments the treatments were in quadruplicates, in all the other experiments in duplicates.

$$
\text { Results }
$$

\section{Mineral nitrogen in the original samples}

Before the incubation the air-dry samples were analyzed for ammonium-nitro gen, nitrate-nitrogen, and nitrite-nitrogen. No nitrite-nitrogen was found, and the ${ }^{-}$ contents of the other forms of mineral nitrogen expressed as grams per kilogram of dry matter and as a percentage of the total nitrogen content of the peat were as follows:

\begin{tabular}{|c|c|c|c|c|c|c|c|c|}
\hline & $\begin{array}{c}1 . \\
\text { SCp }\end{array}$ & $\begin{array}{c}2 . \\
\mathrm{LCp}\end{array}$ & $\begin{array}{c}3 . \\
\mathrm{BC} \mathrm{p}\end{array}$ & $\begin{array}{c}4 . \\
\text { EuSCp }\end{array}$ & $\begin{array}{l}5 . \\
\mathrm{Sp}\end{array}$ & $\begin{array}{c}6 . \\
\text { CSp }\end{array}$ & $\begin{array}{c}7 . \\
\text { LCSp }\end{array}$ & $\begin{array}{l}8 . \\
\text { CSp }\end{array}$ \\
\hline $\mathrm{NH}_{4}-\mathrm{N} \ldots \ldots \ldots$ & 0.22 & 0.25 & 0.12 & 0.11 & 0.23 & 0.20 & 0.35 & \\
\hline $\mathrm{NO}_{3}-\mathrm{N} \quad \ldots \ldots \ldots \ldots$ & 0.03 & 0.05 & 0.06 & 0.15 & 0.12 & 0.06 & 0.07 & \\
\hline $\begin{array}{c}\text { Mineral-N } \ldots \ldots \ldots \\
\text { per cent }\end{array}$ & 0.25 & 0.30 & 0.18 & 0.26 & 0.35 & 0.26 & 0.42 & \\
\hline of total $\mathrm{N} \ldots \ldots \ldots$ & 0.8 & 0.9 & 0.6 & 1.2 & 2.8 & 0.9 & 1.7 & 0.7 \\
\hline
\end{tabular}

The mineral nitrogen content of the peats expressed on the weight basis seems to be rather high, but the fact must be taken into consideration that the volume weight of these samples was extremely low $(0.1-0.3)$. On the other hand, the amount of mineral nitrogen represented only a very small part of the total nitrogen in these samples. It is of interest to notice that the percentage of mineral nitrogen in the Sphagnum fuscum peat was markedly higher than in the other samples. It is, of course, possible that during the drying of the samples a part of the original ammonium nitrogen was transformed to nitrate-nitrogen, and perhaps also a slight increase in the mineral nitrogen content occurred. Anyhow, these values represent the ammonium and nitrate nitrogen contents of the samples in the beginning of the experiments.

\section{Experiments with lime and fertilizers}

Owing to the great amount of treatments in the first incubation experiment the analyses could not be performed within so short a time that the comparison of the various peat series would be quite reliable. Thus the results mainly elucidate the effect of the different treatments upon the mineral nitrogen content of the respective peats. It is probable, however, that no very marked changes occurred during the 
later part of the rather long incubation period, particularly, since the acidity of most of peats was already at that time very high.

The $\mathrm{pH}$-values measured in water suspension (1:4) of the fresh samples were the following:

\begin{tabular}{|c|c|c|c|c|c|c|c|c|}
\hline$x^{3-}$ & $\begin{array}{c}1 . \\
\mathrm{SCp}\end{array}$ & $\begin{array}{c}2 . \\
\mathrm{LCp}\end{array}$ & $\begin{array}{c}3 . \\
\mathrm{BC} \mathrm{p}\end{array}$ & $\begin{array}{c}4 . \\
\text { EuSCp }\end{array}$ & $\begin{array}{l}5 . \\
\text { Sp }\end{array}$ & $\begin{array}{c}6 . \\
\text { CSp }\end{array}$ & $\begin{array}{c}7 . \\
\text { LCSp }\end{array}$ & $\begin{array}{c}8 . \\
\text { CSp }\end{array}$ \\
\hline Incubation period days & 230 & 290 & 300 & 300 & 270 & 280 & 260 & 250 \\
\hline Original $\quad \ldots \ldots \ldots \ldots$ & 4.68 & 4.92 & 4.73 & 5.60 & 3.99 & 4.72 & 4.54 & 4.52 \\
\hline \multicolumn{9}{|l|}{ Treatment } \\
\hline $0 \quad \ldots \ldots \ldots \ldots \ldots$ & 4.32 & 4.56 & 4.75 & 5.75 & 4.65 & 5.95 & 4.16 & 5.63 \\
\hline $\mathrm{PK} \quad \ldots \ldots \ldots \ldots \ldots$ & 4.15 & 4.60 & 4.76 & 5.75 & 4.58 & 4.34 & 4.06 & 4.87 \\
\hline $\mathrm{PK} \mathrm{Cu} \ldots \ldots \ldots \ldots$ & 4.19 & 4.53 & 4.62 & 5.75 & 4.73 & 4.48 & 4.12 & 4.97 \\
\hline $\mathrm{NPK} \mathrm{Cu} \ldots \ldots \ldots \ldots$ & 4.14 & 4.44 & 4.70 & 5.75 & 4.73 & 4.71 & 4.13 & 5.43 \\
\hline $\mathrm{Ca} \ldots \ldots \ldots \ldots \ldots$ & 4.98 & 4.62 & 5.52 & 6.00 & 4.60 & 4.82 & 4.47 & 4.56 \\
\hline $\mathrm{CaPK} \quad \ldots \ldots \ldots \ldots$ & 4.99 & 4.68 & 5.88 & 6.20 & 4.64 & 4.59 & 4.62 & 4.75 \\
\hline $\mathrm{CaPK} \mathrm{Cu} \ldots \ldots \ldots$ & 4.91 & 4.66 & 5.24 & 6.15 & 4.68 & 4.85 & 4.59 & 4.81 \\
\hline CaNPK Cu $\ldots \ldots$. & 5.11 & 4.69 & 5.51 & 6.20 & 4.60 & 4.79 & 4.54 & 4.84 \\
\hline
\end{tabular}

In a previous publication (2) one of the authors demonstrated that in incubation experiments, and probably, in a lower degree, also under natural conditions, the changes in the $\mathrm{pH}$-values of slightly humified peats are closely connected with the increases or decreases in their ammonia and nitrate nitrogen contents. Also differences in the $\mathrm{pH}$-values of these variously treated samples are, at least partly, explained by the corresponding ammonia and nitrate nitrogen contents presented in Figure 1.

These results are quite consistent in so far that a high ammonia content always means a high $\mathrm{pH}$-value and a high nitrate-content a low $\mathrm{pH}$-value. But the effect of the various treatments is not equally marked. Some pronounced trends can, however, be seen.

Generally, accumulation of nitrate-nitrogen was intensive in the limed samples. This, of course, was the main reason for the remarkably low $\mathrm{pH}$-values in most of these samples. In the Sphagnum fuscum peat no nitrate-nitrogen was formed without lime, and also in the CSp-sample 8 nitrification was far more intensive in the limed pots. In all the other peats lime was not necessary for the accumulation of nitratenitrogen, although in its presence somewhat higher nitrate-contents were measured. Ammonium nitrogen content was low in all the limed peats.

The effect of lime upon the changes in the nitrogen compounds of the peats in this experiment may be presented by the following figures which represent the average increase $(\mathrm{g} / \mathrm{kg})$ in the mineral nitrogen contents of the peat samples due to the liming:

\begin{tabular}{|c|c|c|c|c|c|c|c|c|}
\hline Increase in & $\begin{array}{c}1 . \\
\mathrm{SCp}\end{array}$ & $\begin{array}{c}2 . \\
\mathrm{LCp}\end{array}$ & $\begin{array}{c}3 . \\
\mathrm{BC} \mathrm{p}\end{array}$ & $\begin{array}{c}4 . \\
\text { EuSCp }\end{array}$ & $\begin{array}{l}5 . \\
\text { Sp }\end{array}$ & $\begin{array}{c}6 . \\
\text { CSp }\end{array}$ & $\begin{array}{c}7 . \\
\text { LCSp }\end{array}$ & $\begin{array}{c}8 . \\
\text { CSp }\end{array}$ \\
\hline $\mathrm{NH}_{4}-\mathrm{N}$ & -0.21 & -0.27 & -0.03 & 0.01 & -1.00 & -0.61 & -0.17 & -0.82 \\
\hline $\mathrm{O}_{3}-\mathrm{N} \quad \ldots \ldots \ldots$ & 0.16 & 0.63 & 0.21 & 0.11 & 1.32 & 0.47 & -0.01 & 0.66 \\
\hline Iineral $\mathrm{N} \ldots \ldots \ldots$ & -0.05 & 0.36 & 0.18 & 0.12 & 0.32 & -0.14 & -0.18 & -0.16 \\
\hline
\end{tabular}




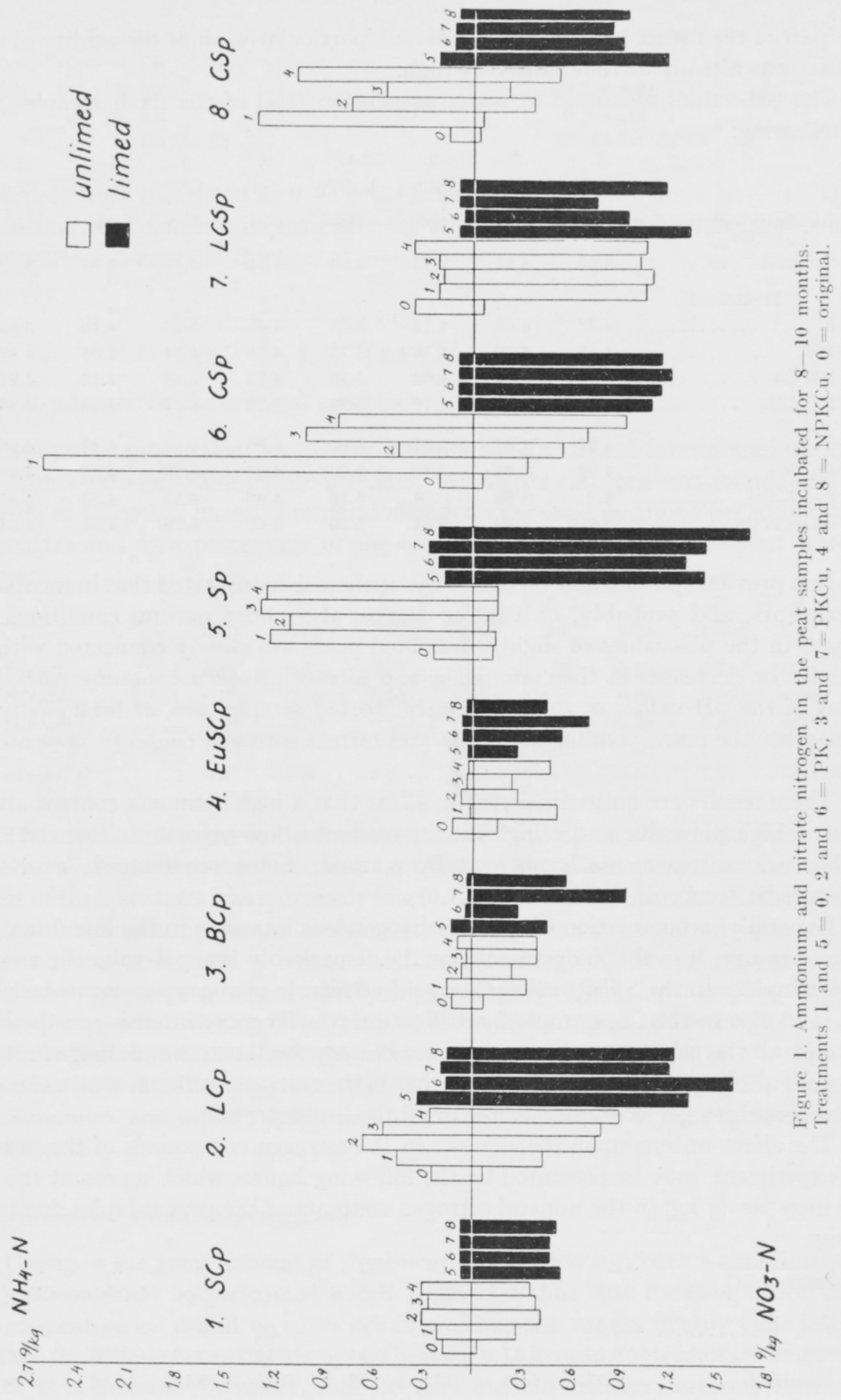


It is of interest to notice that under the conditions of this experiment the average effect of liming upon the accumulation of mineral nitrogen in Sphagnum-peats $6-8$ was not positive. In some cases lime probably stimulated the microbiological immobilization of nitrogen, in other cases the loss of nitrogen connected with the process of nitrification, could be the reason for the lower accumulation of mineral nitrogen in the presence of lime. On the other hand, a marked increase in the total mineral nitrogen content of the fen peats $2-4$ occurred by the liming.

The fact that lime is not necessary for the nitrification in peat soils, although it accelerates the process markedly, was discussed in a previous publication (2), and the assumption was presented that the ammonification may, at least locally, decrease the acidity in such a degree that the activity of the nitrifying organisms is not prevented. This is a probable explanation also for the results of the present experiment, as can be seen from the following $\mathrm{pH}$-values measured in the water-suspensions of the peat samples incubated for only one month:

\begin{tabular}{|c|c|c|c|c|c|c|c|c|}
\hline & $\begin{array}{c}1 . \\
\mathrm{SC}_{\mathrm{p}}\end{array}$ & $\begin{array}{c}2 . \\
\mathrm{LCp}\end{array}$ & $\begin{array}{c}3 . \\
\mathrm{BC}_{\mathrm{p}}\end{array}$ & $\begin{array}{c}4 . \\
\text { EuSCp }\end{array}$ & $\begin{array}{l}5 . \\
\text { Sp }\end{array}$ & $\begin{array}{c}6 . \\
\mathrm{CSp}\end{array}$ & $\begin{array}{c}7 . \\
\text { LCSp }\end{array}$ & $\begin{array}{c}8 \\
\operatorname{CSp}\end{array}$ \\
\hline Original & 4.68 & 4.92 & 4.73 & 5.60 & 3.99 & 4.72 & 4.54 & 4.52 \\
\hline Treatment & & & & & & & & \\
\hline $0 \quad \ldots \ldots \ldots \ldots \ldots$ & 5.14 & 5.23 & 5.50 & 6.23 & 4.89 & 5.36 & 5.21 & 5.01 \\
\hline $\mathrm{PK} \quad \ldots \ldots \ldots \ldots$ & 5.09 & 5.29 & 5.55 & 6.16 & 4.78 & 5.38 & 5.27 & 4.99 \\
\hline $\mathrm{PK} \mathrm{Cu} \ldots \ldots \ldots$ & 5.04 & 5.25 & 5.66 & 6.28 & 4.58 & 5.57 & 5.55 & 5.01 \\
\hline NPK Cu $\quad \ldots \ldots \ldots$ & 5.28 & 4.49 & 5.55 & 6.27 & 4.77 & 5.60 & 5.29 & 5.30 \\
\hline$\ldots \ldots \ldots \ldots$ & 6.16 & 5.47 & 6.97 & 6.73 & 5.87 & 6.40 & 6.24 & 5.95 \\
\hline CaPK $\ldots . . . \ldots$ & 6.24 & 5.50 & 7.11 & 6.84 & 6.05 & 6.50 & 6.21 & 6.09 \\
\hline $\mathrm{CaPK} \mathrm{Cu} \ldots \ldots$. & 6.29 & 5.52 & 7.07 & 6.86 & 6.17 & 6.49 & 6.46 & 6.02 \\
\hline CaNPK $\mathrm{Cu} \ldots \ldots$ & 6.21 & 5.48 & 6.95 & 6.83 & 5.87 & 6.23 & 6.39 & 5.97 \\
\hline
\end{tabular}

The increase in the $\mathrm{pH}$-values of every peat during the first month of incubation was so marked that considerable amounts of ammonia must have been liberated from the organic compounds. Only the unlimed samples of Sp were continually distinctly acid, and they were the samples in which no nitrification in spite of the high ammonium nitrogen content could be demonstrated during the prolonged incubation (cf. Figure 1).

The results given by Figure 1 of the effect of fertilizers upon the mineralization of nitrogen in various peats are not distinct. Generally, the differences between the various treatments were small, and in most cases within the limits of analytical errors. So, for example, it can be claimed that applications of phosphorus and potassium, or copper, or mineral nitrogen exerted no influence upon the mobilization of nitrogen in samples 1 and 5, in the unlimed series of the sample 7 , and in the limed series of the sample 6. Phosphorus and potassium fertilization somewhat increased the amount of ammonium and nitrate nitrogen in the unlimed sample 2 , and in the limed sample 4 , but in the unlimed samples $3,4,6$, and 8 , and in the limed samples 3,7 , and 8 a contradictory effect was obtained. The positive effect of copper sulphate was negligible in all the other samples but in the limed samples 3 and 4. 
The effect of various treatments upon the increase in the mineral nitrogen content of the peats, expressed as a percentage of the total nitrogen content, can be seen from the following figures:

\begin{tabular}{|c|c|c|c|c|c|c|c|c|}
\hline Treatment & $\begin{array}{c}1 . \\
\text { SCp }\end{array}$ & $\begin{array}{c}2 . \\
\mathrm{LCp}\end{array}$ & $\begin{array}{c}3 . \\
\mathrm{BCp}\end{array}$ & $\begin{array}{c}4 . \\
\text { EuSCp }\end{array}$ & $\begin{array}{l}5 . \\
\text { Sp }\end{array}$ & $\begin{array}{c}6 . \\
\mathrm{CSp}\end{array}$ & $\begin{array}{c}7 . \\
\text { LCSp }\end{array}$ & $\begin{array}{r}8 . \\
\text { CSp }\end{array}$ \\
\hline$\ldots \ldots \ldots \ldots \ldots$ & 0.7 & 1.8 & 1.0 & 1.2 & 8.2 & 9.0 & 3.4 & 4.4 \\
\hline $\mathrm{PK} \quad \ldots \ldots \ldots \ldots$ & 1.5 & 3.5 & 0.4 & 0.2 & 6.9 & 2.5 & 3.5 & 3.8 \\
\hline $\mathrm{PK} \mathrm{Cu} \ldots \ldots \ldots$ & 1.3 & 3.2 & 0.8 & 0 & 8.6 & 4.9 & 3.3 & 2 \\
\hline NPK $\mathrm{Cu} \quad \ldots . .$. & 0.4 & 1.8 & 0 & -0.3 & 6.1 & 4.0 & 2.8 & 4.1 \\
\hline$\ldots \ldots \ldots$ & 1.1 & 4.3 & 1.3 & 0.2 & 10.0 & 3.1 & 4.0 & 4 \\
\hline $\mathrm{CaPK} \quad \ldots \ldots \ldots \ldots$ & 0.9 & 4.6 & 0.3 & 1.4 & 9.4 & 3.3 & 2.4 & 3. \\
\hline $\mathrm{CaPK} \mathrm{Cu} \ldots \ldots .$. & 0.9 & 3.4 & 2.4 & 2.1 & 10.8 & 3.4 & 1.9 & . \\
\hline $\mathrm{CaNPK} \mathrm{Cu} \ldots \ldots$ & 0 & 2.5 & 0.3 & -0.3 & 9.9 & 2.2 & 2.2 & 2.8 \\
\hline
\end{tabular}

According to these data the effect of mineral nitrogen fertilizer was negligible or negative in almost all the peats and in the limed series as well as in the unlimed ones. Attention must be paid to the fact that the amount of mineral nitrogen applied in the beginning of the experiment was subtracted from the analyzed values before the percentages were calculated. Anyhow, these results clearly indicate that either denitrification or microbiological immobilization of this added nitrogen occurred in the peat samples.

However, the fact must be remembered that all these analytical results present only a temporary situation in the continuous processes of ammonification, nitrification, denitrification, and microbiological immobilization of nitrogen. No reliable picture about the total amount of mobilized or mobilizable nitrogen in the peats can be obtained by experiments of this kind.

According to the results presented above some marked differences in the accumulation of mineral nitrogen in these peat samples can be stated. The very slight increase in the mineral nitrogen content of the fen peats 3. BCp and 4. EuSCp, as well as in the SCp, sample 1, that was analyzed two months before the first mentioned peats, can be explained to be due to the high availability of the carbon compounds in these peats. The absence of available carbon sources may be the reason for the marked accumulation of mineral nitrogen in the Sphagnum peats 5.-8, but also the fen peat 2. LCp belonged to this group.

This experiment was carried out under far more favourable conditions than those prevailing in nature. The temperature was considerably high, $16-22^{\circ} \mathrm{C}$, the moisture content was kept at the optimum, and the grinding of the samples had made the material more attackable by the microorganisms. Probably also the composition of the microflora was different form the native one. Anyhow, on the basis of this experiment the nitrogen compounds in the Sphagnum peats seem to be at least equally decomposable as those in the fen peats. If in this respect some superiority of the fen peats under the natural conditions exists, it must depend on other factors than on the quality of the nitrogen compoinds, at least if only slightly decomposed peats are in question. 


\section{Incubation period 1 month}

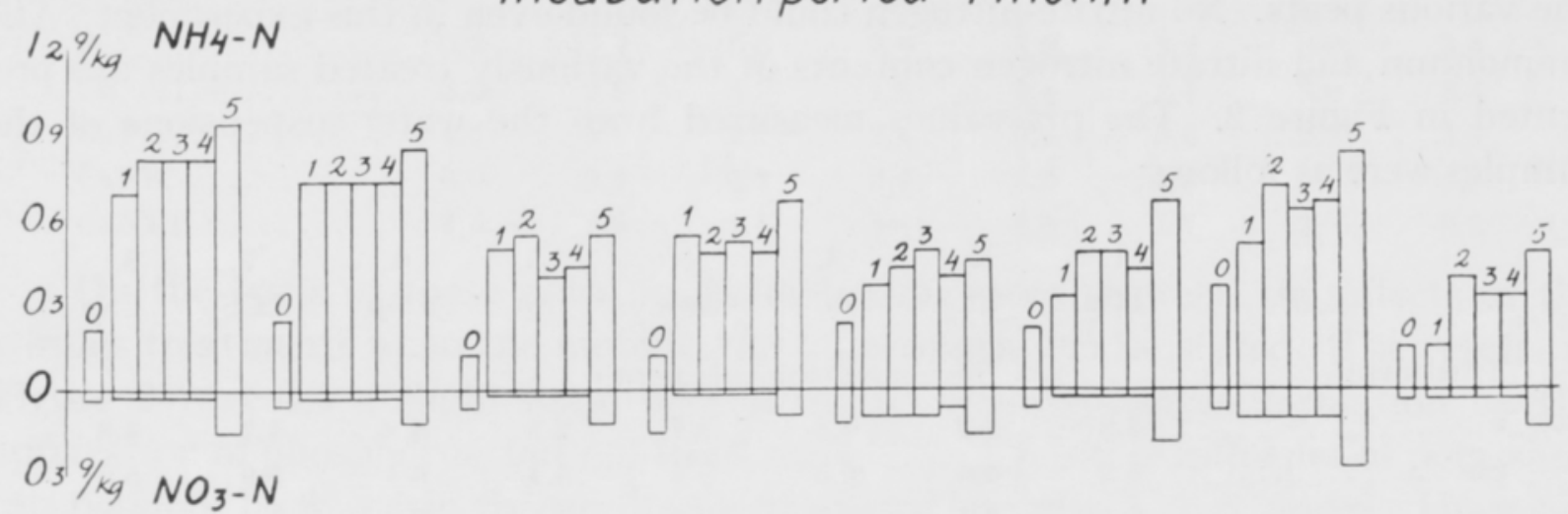

$\begin{array}{lllllllll}\text { 1. } S C P & \text { 2. } L C P & 3 . B C p & \text { 4. EuSCP } & \text { 5.SP } & \text { 6.CSp } & \text { 7. LCSP } & \text { 8.CSp }\end{array}$ Incubation period 6 months

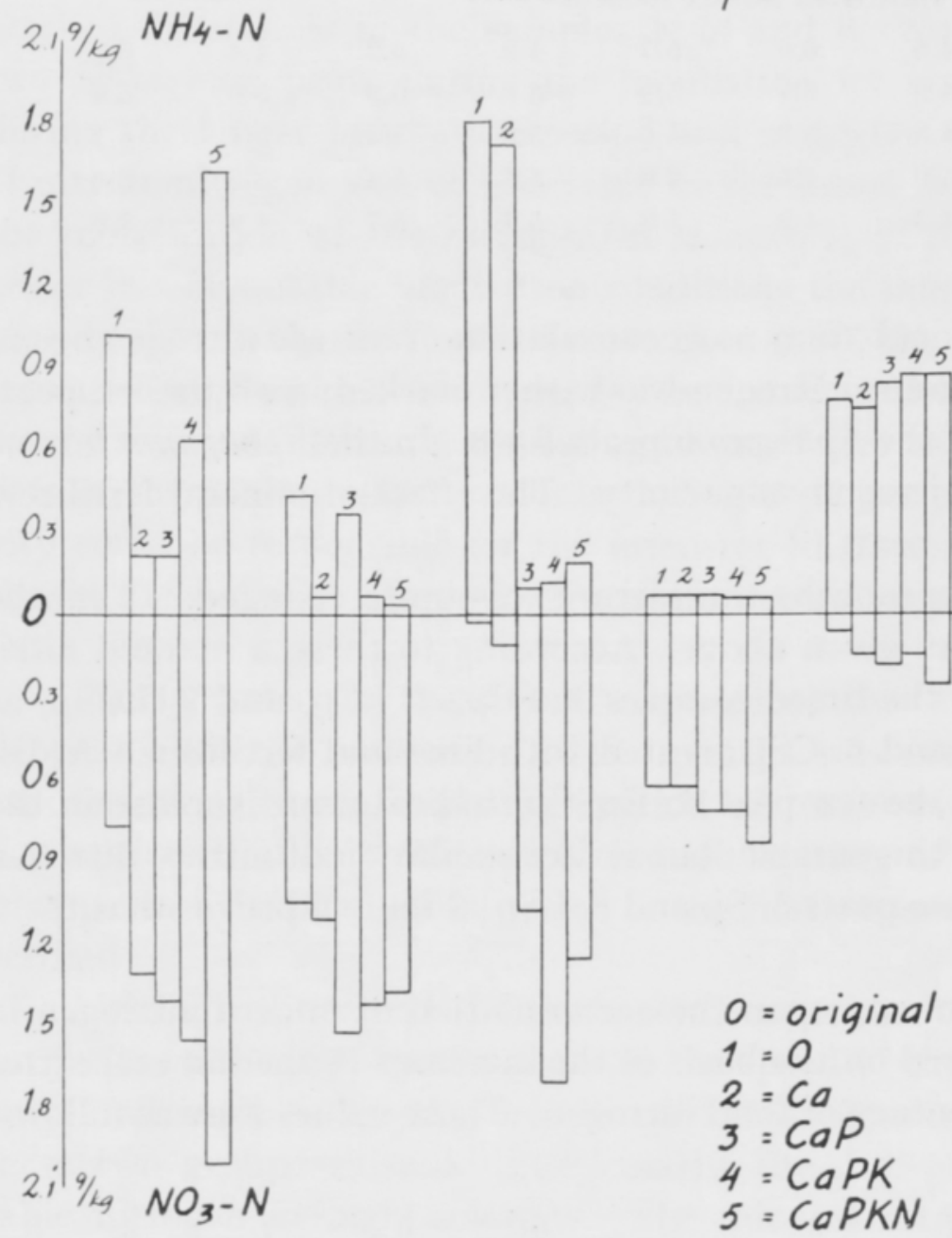

Figure 2. Ammonium and nitrate nitrogen in the peat samples incubated for one month and six months. (The application of nitrogen in the 5 . treatment corresponded to $0.15 \mathrm{~g} / \mathrm{kg}$ of ammonium nitrogen and to $0.15 \mathrm{~g} / \mathrm{kg}$ of nitrogen.)

The second incubation experiment with these samples carried out at markedly lower temperatures than the first one and analysed after periods of one month and of six months was apt for the comparison of the accumulation of mineral nitrogen in 
the various peats. No nitrite-nitrogen could be found even in this experiment. The ammonium and nitrate nitrogen contents of the variously treated samples are presented in Figure 2. The pH-values measured from the water-suspensions of the samples were as follows:

\begin{tabular}{|c|c|c|c|c|c|c|c|c|}
\hline & $\begin{array}{c}1 . \\
\text { SCp }\end{array}$ & $\begin{array}{c}2 . \\
\mathrm{LCp}\end{array}$ & $\begin{array}{c}3 . \\
\mathrm{BCp}\end{array}$ & $\begin{array}{c}4 . \\
\text { EuSCp }\end{array}$ & $\begin{array}{c}5 . \\
\text { Sp }\end{array}$ & $\begin{array}{c}6 . \\
\text { CSp }\end{array}$ & $\begin{array}{c}7 . \\
\text { LCSp }\end{array}$ & $\begin{array}{l}8 . \\
\text { CSp }\end{array}$ \\
\hline Treatment & \multicolumn{8}{|c|}{ Incubated for one month } \\
\hline $0 \quad \ldots \ldots \ldots \ldots \ldots$ & 4.8 & 5.2 & 4.8 & 5.7 & 3.8 & 4.8 & 4.7 & 4.6 \\
\hline $\mathrm{Ca} \ldots \ldots \ldots \ldots$ & 6.2 & 5.9 & 6.5 & 6.4 & 5.4 & 6.1 & 5.9 & 5.9 \\
\hline $\mathrm{CaP} \quad \ldots \ldots \ldots \ldots$ & 6.4 & 6.1 & 6.7 & 6.5 & 5.5 & 6.2 & 6.2 & 6.1 \\
\hline $\mathrm{CaPK} \quad \ldots \ldots \ldots$ & 6.2 & 5.9 & 6.5 & 6.4 & 5.4 & 6.2 & 5.9 & 6.0 \\
\hline CaPKN $\ldots \ldots \ldots$ & 6.2 & 5.9 & 6.4 & 6.4 & 5.3 & 6.1 & 5.9 & 5.9 \\
\hline \multicolumn{9}{|c|}{ Incubated for six months } \\
\hline $0 \quad \ldots \ldots \ldots \ldots \ldots$ & 4.8 & 4.6 & 6.0 & 5.7 & 4.9 & 5.7 & 4.4 & 5.9 \\
\hline $\mathrm{Ca} \ldots \ldots \ldots \ldots$ & 4.7 & 4.9 & 6.7 & 5.9 & 5.8 & 5.9 & 5.0 & 6.4 \\
\hline CaP $\ldots \ldots \ldots \ldots$ & 4.9 & 4.8 & 5.3 & 6.0 & 5.9 & 5.6 & 5.1 & 6.3 \\
\hline CaPK $\quad \ldots \ldots \ldots$ & 4.9 & 4.9 & 4.6 & 6.0 & 5.8 & 5.4 & 5.0 & 6.6 \\
\hline CaPKN ......... & 4.9 & 4.9 & 4.9 & 5.9 & 5.7 & 5.7 & 4.9 & 6.6 \\
\hline
\end{tabular}

During the first month of incubation no accumulation of nitrate nitrogen occurred, but the liberation of ammonium nitrogen was rather marked in all the fen peats and also in the limed samples of the Sphagnum peats $6-8$. In the Sphagnum fuscum sample the ammonification of nitrogen was scanty. The effect of mineral fertilizers was almost negligible in all the peats.

After the incubation for six months the picture was quite changed. It can be seen already from the $\mathrm{pH}$-values given above. According to these a marked nitrification must have occurred in the limed samples 1. SCp, 2. LCp, and 7. LCSp, as well as in the samples 3. BCp and 6. CSp treated with lime and fertilizers. A distinct drop in the $\mathrm{pH}$-values of the fen peat 4. EuSCp, indicates an increase in the nitrate-nitrogen content also in this sample, but no accumulation of nitrate nitrogen is to be expected in the Sphagnum peats 5. Sp and 8. CSp. Figure 2 proves that these assumptions are right.

The effect of various treatments upon the accumulation of mineral nitrogen in the peat samples can be compared on the basis of the increases in the mineral nitrogen content expressed as a percentage of total nitrogen. These values were as follows:

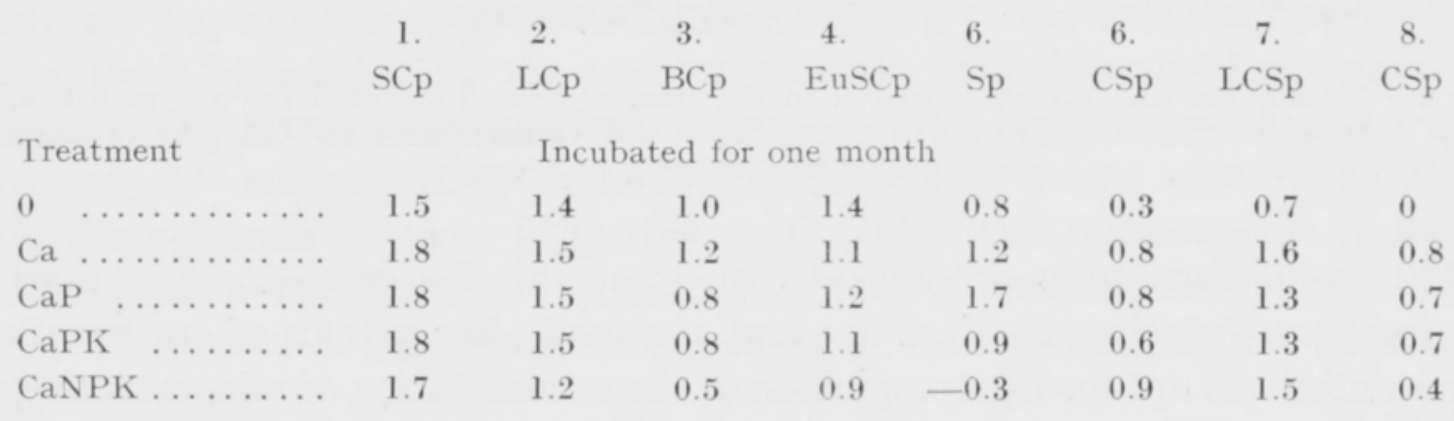




\begin{tabular}{llllllllll}
\multicolumn{10}{c}{ Incubated for six months } \\
$0 \quad \ldots \ldots \ldots \ldots \ldots$ & 5.3 & 3.7 & 5.3 & 2.0 & 3.9 & 3.2 & 2.2 & 3.4 \\
$\mathrm{Ca} \ldots \ldots \ldots \ldots \ldots$ & 3.9 & 2.8 & 5.2 & 1.9 & 4.4 & 2.1 & 3.0 & 3.4 \\
$\mathrm{CaP} \quad \ldots \ldots \ldots \ldots \ldots$ & 4.2 & 5.1 & 3.1 & 2.4 & 5.4 & 3.6 & 2.9 & 3.8 \\
$\mathrm{CaPK} \quad \ldots \ldots \ldots \ldots$ & 6.0 & 3.6 & 5.2 & 2.4 & 5.3 & 4.8 & 3.2 & 5.0 \\
$\mathrm{CaNPK} \ldots \ldots \ldots \ldots$ & 9.5 & 2.6 & 3.1 & 1.6 & 4.0 & 1.7 & 3.0 & 6.3
\end{tabular}

On the basis of these data no distinct differences between the effects of the various treatments upon the mobilization of nitrogen can be stated. The results in Figure 2 reveales a slight improvement of the nitrate-nitrogen formation by the application of phosphorus, but not in all the peats. A positive influence of potassium can possibly be found in the results for the limed samples $1,3,6$, and 8 . However, it seems not to be justifiable to claim that potassium or phosphorus were necessary, not even beneficial for the accumulation of mineral nitrogen in these peat samples.

As compared with the results of the first experiment these data show the most marked differences in the samples 1, 5, and 8. No nitrification occurred in these two Sphagnum peats during the incubation for six months at $10-15^{\circ}$, whereas during the longer incubation period and at higher temperatures the accumulation of nitrate-nitrogen was considerable in the limed samples. In the first experiment the mobilization of the nitrogen in sample 1. SCp was surprisingly scanty while under less favourable incubation conditions the mineral nitrogen content increased already during the first month more than in all the other samples. An explanation for this disagreement could possibly be found in the fact that in the second experiment an abundant fauna, consisting of small flies and their larvae, developed in the pots of the SCp-samples, yet only during the later period of incubation. Their activity could be responsible for the intensive liberation of nitrogen. Flies were found also in the series of sample 8. CSp in the second experiment, but were absent in the other series.

The fact that in the second experiment the mineral nitrogen content of the BC-peat after the incubation of six months was markedly higher than in the first experiment after an incubation period of ten months could be explained by the assumption that microbiological immobilization of nitrogen occurred during the later part of the incubation period in the first experiment. However, this cannot be verified.

Although the results of the second experiment showed the superiority of the fen peats to the Sphagnum peats in the speed of the nitrogen mineralization in the untreated samples, in the limed and fertilized samples no marked limit between these two groups existed. Particularly the LCS-peat contained rapidly mobilizable nitrogen in high amounts. The mineral nitrogen content of the untillable Sphagnum fuscum peat was also surprisingly high. On the other hand, the EuSCpeat that originated from the best kind of peat soils liberated its nitrogen only in a low degree.

\section{Experiment with wood ash}

Wood ash is known to contain large amounts of potassium, phosphorus and neutralizing compounds, as well as valuable trace elements. The effect of ash upon 
Table 4. Influence of ash upon the mineral nitrogen content of the incubated SC-peat (Expressed as grams per kilogram of dry matter)

\begin{tabular}{|c|c|c|c|c|c|c|c|c|}
\hline \multirow{2}{*}{ Treatment } & \multicolumn{3}{|c|}{ Incubated for 3 months } & & \multicolumn{4}{|c|}{ Incubated for 10 months } \\
\hline & $\mathrm{pH}$ & $\mathrm{NH}_{4}-\mathrm{N}$ & $\mathrm{NO}_{3}-\mathrm{N}$ & Total & $\mathrm{pH}$ & $\mathrm{NH}_{4}-\mathrm{N}$ & $\mathrm{NO}-\mathrm{N}_{3}$ & Total \\
\hline 0 & 4.74 & 1.31 & 0.79 & 2.10 & 4.45 & 2.77 & 0.90 & 3.67 \\
\hline Ash $2 \mathrm{t} / \mathrm{ha}$ & 4.60 & 0.21 & 0.97 & 1.18 & 4.24 & 1.40 & 1.01 & 2.41 \\
\hline Ash $10 \mathrm{t} / \mathrm{ha}$ & 5.49 & 0.10 & 1.53 & 1.63 & 4.45 & 0.12 & 1.13 & 1.25 \\
\hline Ash $2 \mathrm{t} / \mathrm{ha}+\mathrm{PK} \quad \ldots$. & 4.56 & 0.38 & 1.00 & 1.38 & 4.15 & 0.61 & 0.67 & 1.28 \\
\hline Ash $2 \mathrm{t} / \mathrm{ha}+\mathrm{CaPK} \ldots$ & 5.26 & 0.09 & 1.58 & 1.67 & 4.40 & 0.13 & 1.00 & 1.13 \\
\hline
\end{tabular}

the mineralization of nitrogen in the SC-peat was studied by an incubation experiment in which the samples were analyzed after periods of three and ten months. The results are presented in Table 4.

These data give a lot of problems to be solved. The most striking fact is that the accumulation of mineral nitrogen was highest in the untreated sample, both after three months and after ten months. After the latter period a mobilization of nitrogen corresponding to about ten per cent of the total nitrogen content of this peat was estimated. This yield was due to the high ammonium nitrogen content of the untreated samples; the nitrate-nitrogen concentration was nearly equal to that of the treated samples.

The influence of ash upon the changes in the peat nitrogen most probably was due to its neutralizing agencies. As low an amount as $2 \mathrm{t} /$ ha quite distinctly decreased the accumulation of ammonium nitrogen during the first part of the incubation. In this respect, the influence of 10 tons of ash per hectare or the influence of both ash and lime was even more effective.

In this experiment also the treatment with potassium and phosphorus seemed to exert a slight effect upon the accumulation of mineral nitrogen. But its effect as well as the effect of ash and lime was negative. Similar trends were found also in some peats in the first and second experiments, and possibly they can be explained on the basis that the treatments made peat carbon more available to the microbes. No loss of nitrogen by volatilization as ammonia can be expected to have occurred from the samples treated by ash without or with lime and fertilizers during the time between the first and the second analyses, since the samples were distinctly acid already after the incubation for three months. But quite in the beginning of the experiment, when the sampels treated with $10 \mathrm{t} / \mathrm{ha}$ of ash or with ash and lime, certainly had a high $\mathrm{pH}$ value, the possibility for some loss of ammonia was not excluded. In addition to these the complex processes of denitrification must be taken into consideration.

\section{Experiment with trace elements.}

In the incubation experiments in which the effect of copper sulphate, zinc chloride, and ammonium molybdate upon the changes in the mineral nitrogen content of the fen peats 4. EuSCp and 2. LCp, and the Sphagnum peats 8. CSp and 6. CSp was studied, no significant differences between the untreated and treated samples could be found. Therefore, the date are not reported here. 


\section{Discussion}

The results reported in the present paper are not in accordance with the general opinion that the fen peats are markedly superior to the Sphagnum peats. If the quite undecomposed Sphagnum fuscum sample is excluded, the chemical characteristics of the four fen peats with a virgin productivity of $6-8$ and those of the three Sphagnum peats with a virgin productivity of $2-3$ varied within the following limits:

\begin{tabular}{|c|c|c|}
\hline $\mathrm{pH}_{\mathrm{H}_{2} \mathrm{O}}$ & $\begin{array}{l}\text { Fen peats } \\
4.68-5.60\end{array}$ & $\begin{array}{c}\text { Sphagnum peats } \\
4.52-4.72\end{array}$ \\
\hline$\ldots \ldots \ldots \ldots \ldots \ldots \ldots \ldots$ & $3.68-5.24$ & $3.72-3.82$ \\
\hline Ash content $\ldots \ldots$. & $4.1-7.2 \%$ & $7.5-11.7 \%$ \\
\hline Total N content & $2.21-3.24 \%$ & $2.47-2.99 \%$ \\
\hline Total P content.... & $0.05-0.13 \%$ & $0.08-0.14 \%$ \\
\hline "Hemicelluloses" & $10.1-13.3 \%$ & $9.2-12.9 \%$ \\
\hline Cellulose ........ & $6.5-13.8 \%$ & $4.6-9.4 \%$ \\
\hline $\mathrm{NH}_{4}-\mathrm{N} g / \mathrm{kg} \quad \ldots \ldots \ldots \ldots \ldots \ldots$ & $0.11-0.25$ & $0.14-0.35$ \\
\hline $\mathrm{NO}_{3}-\mathrm{Ng} / \mathrm{kg} \quad \ldots \ldots \ldots \ldots \ldots \ldots$ & $0.03-0.15$ & $0.04-0.07$ \\
\hline Mineral $\mathrm{N}$ as a percentage of total $\mathrm{N}$ & $0.6-1.2 \%$ & $0.7-1.7 \%$ \\
\hline
\end{tabular}

It is impossible to claim on the basis of these data that any significant difference existed between the two peat groups. And also the results of the incubation experiments did not draw any marked line between the mineral nitrogen accumulation of the fen peats and that of the Sphagnum peats: the average increase in mineral nitrogen after an incubation of six months in the second experiment varied from 2.1 to 5.8 expressed as a percentage of the total nitrogen in the fen peats, the corresponding limits for the Sphagnum peats being 2.9 and 4.4. Only after an incubation period of one month the increase in the mineral nitrogen of the untreated fen peats was distinctly higher than that of the untreated Sphagnum samples.

One of the main reasons for these results can possibly be found in the rather low degree of decomposition of all the peat samples. The differences in the characteristics of the fen peats and the Sphagnum peats probably develop during the humification under natural conditions where e.g. the structure of the material exerts its effect upon the decomposition.

In addition to this the fact must be remembered that although the average values of large materials may in several respects show a difference between these two peat groups, the variation of the original data is always relatively high, and it is doubtful, if any statistically significant difference can be found. This may be seen e.g. from the total nitrogen content of various kinds of peats reported by KIVINEN (3). Thus these samples, although from quite typical fen peat lands and bogs, cannot be supposed to represent just the average characteristics of their groups.

As to the results of the incubation experiments, the limits of this kind of studies prevents the demonstration of the real rate of nitrogen mobilization in the peat samples. They give only the situation at a certain moment. Thus the fact that no marked differences could be determined in the accumulation of mineral nitrogen in the fen peats and the Sphagnum peats does not mean that mobilization had been equal in them. But it shows that under favourable conditions the Sphagnum peats can accu- 
mulate mineral nitrogen as much as fen peats, and even more. Also it can be stated that there are no reasons to suppose that the nitrogen compounds of the Sphagnum peats were less easily available to the microorganisms than those of the fen peats. If they seem to be such under natural conditions, it must be due to the less favourable conditions, particularly the bad structure of the bogs, to the protective effect of the cell walls and other constituents upon the nitrogen compounds of the moss cells.

\section{$S u m m a r y$}

An attempt has been made to elucidate the influence of lime and fertilizers upon the mineralization of peat nitrogen under laboratory conditions. The main object was to study differences between the responce of various kinds of peats to these treatments and to the incubation under conditions favourable for the activity of microorganisms.

The material consisted of eight peat samples from North Finland. Four of them were fen peats with a virgin productivity of $6-8$. The other four originated from untillable bogs with a virgin productivity of $1-3$. All the samples were from virgin peat lands and only slightly decomposed.

In spite of the different origins of these peat groups no marked differences in their chemical composition and characteristics could be found. This was supposed to be due to their low degree of decomposition.

In the first large incubation experiment carried out at $15^{\circ}-22{ }^{\circ} \mathrm{C}$ the accumulation of nitrate-nitrogen during the $8-10$ months of incubation was relatively high in all the limed samples, but marked nitrification occurred also in most of the unlimed samples, the Sphagnum fuscum peat being the most prominent exception. On the average, the effect of lime upon the total accumulation of mineral nitrogen was positive only in three of the fen peats and in the Sphagnum fuscum sample.

In the second experiment lime seemed to stimulate the ammonification in the Sphagnum peats during the first month of incubation, but later on the accumulation of mineral nitrogen was found to be almost equally intensive in the limed and unlimed samples.

No significant effect of potassium, phosphorus and nitrogen fertilizers could be stated in the incubation experiments. The same was true in respect to the effect of copper sulphate, zinc chloride or ammonium molybdate.

The influence of ash upon the changes in the mineral nitrogen content of one fen peat was supposed to be due to its neutralizing agencies. The accumulation of mineral nitrogen, particularly of ammonium nitrogen, was highest in the untreated samples.

Although some superiority of the fen peats to the Sphagnum peats in respect to the speed of the accumulation of mineral nitrogen could be stated, the differences between these groups after the prolonged incubation were negligible. This can be explained by the different intensity of immobilization and denitrification of nitrogen in these peats under the conditions of the experiments. It also may be taken to mean that no distinct differences existed between the decomposability of the nitrogen compounds of these slightly humified fen peats and Sphagnum peats. 


\section{REFERENCES}

(1) Fraser, G. K. 1943. Peat deposits of Scotland. Part I. Dept. Scient. \& Ind. Res. Geol. Survey Great Britain: Scotland. Wartime Pamphlet n:o 36, 55 p.

(2) KailA, A. 1954. Nitrification in decomposing organic matter. Acta Agr. Scand., 4, p. $17-32$.

(3) Kivinen, E. 1934. Über die organische Zusammensetzung der Torfarten und einiger Torfkonstituenten. Acta Agr. Fennica, 31, p. 165-200.

(4) von Post, L. 1924. Das genetische System organogenen Bildungen Schwedens. Com. Intern. Pédol. IV Comm., 22, p. $287-304$.

(5) Springer, U. 1940. Humifizierung und Zersetzung und ihre Bestimmung in Torfen, Stallmisten und anderen organischen Bildungen. Bodenk. u. Pflanzenern., 18, p. 129-167.

(6) Waksman, S. A. and Stevens, K. R. 1928. Contribution to the chemical composition of peat. I. Soil Sci, 26, p. $113-137$.

(7) Wilson, B. D. and Staker, E. V. 1933. The character of the peat deposites of New York. Cornell Univ. Agr. Exp. Sta., Mem. 149, 20 p.

\section{S E L O S T U :}

\section{KALKIN JA LANNOITTEIDEN VAIKUTUKSESTA TURPEEN TYPEN MINERALOITUMISEEN MUHITUSKOKEISSA}

Armi Kaila, Sylvi Soini ja Erkki Kivinen

Yliopiston maanviljelyskemian laitos, Helsinki

Edellä selostetuissa muhituskokeissa tutkittiin kalkin, kali-, fosfaatti- ja typpilannoitteiden sekä tuhkan, kuparin, sinkin ja molybdeenin vaikutusta turvenäytteiden mineraalitypen kertymiseen. Erityisesti kiinnitettiin huomiota eri turvelajien välisiin eroihin.

Aineistona oli kahdeksan pohjois-Suomen tyypillisiltä, luonnontilaisilta soilta otettua turvenäytettä. Näytteet $1-4$ olivat viljelyskelpoisilta soilta, Bo $6-8$, näytteet $5-8$ rahkasoilta, joiden boniteetti oli $1-3$. Kaikki näytteet olivat soiden pintaosasta ja heikosti maatuneita.

Huolimatta erilaisesta viljelysarvostaan nämä turveryhmät osoittautuivat kemiallisilta ominaisuuksiltaan yllättävän samanlaisiksi, ainoana poikkeuksena oli maatumaton Sphagnum fuscum-turve, näyte 5. Tähän lienee syynä lähinnä turpeiden alhainen maatumisaste.

Kalkitus näytti yleensä edistävän nitrifikaatiota, joskin melkoista nitraattitypen kertymistä oli havaittavissa myös kalkitsemattomissa näytteissä $8-10$ kk muhituksen aikana. Kalkin vaikutus mineraalitypen kokonaismäärään oli sen sijaan useissa tapauksissa negatiivinen.

Tuhkan vaikutus näytti kytkeytyvän lähinnä sen neutraloiviin ominaisuuksiin. Hivenaineilla, samoin kuin kali- ja fosfaattilannoitteilla ei voitu todeta olevan selvää vaikutusta turpeen typen muutoksiin. Typpilannoitteet alensivat useissa tapauksissa kertyneen mineraalitypen määrää.

Vaikka muhituskokeiden tulokset osoittivat melkoisia eroja eri turvelajien mineraalitypen kertymisessä, selvää rajaa ei ollut havaittavissa eri turveryhmien välillä. Ainoastaan muhituksen alkuvaiheessa näytti typen ammonifioituminen olevan hiukan nopeampaa kalkitsemattomissa ja lannoittamattomissa mutasuoturvenäytteissä kuin vastaavissa rahkaturpeissa. On tietenkin otettava huomioon, että tällaisten kokeitten tulokset osoittavat ainoastaan mineraloitumisen, immobilisoitumisen ja denitrifikaation yhteisvaikutusta turpeen typen muutoksiin. Prosessit ovat siis voineet olla hyvinkin erilaiset eri näytteissä samanlaisesta lopputuloksesta huolimatta

Laboratoriokokeet, joissa jauhettua turvetta on muhitettu mahdollisimman suotuisissa olosuhteissa ja joissa kasvien ravinteiden otto sekä ravinteiden huuhtoutuminen eivät pääse vaikuttamaan, antavat tuloksia, jotka voivat poiketa huomattavasti kentällä saatavista. Näitten kokeitten perusteella näyttää kuitenkin siltä, etteivät heikosti maatuneiden rahkaturpeiden typpiyhdisteet olisi sen vaikeammin hajaantuvia kuin heikosti maatuneiden mutasuoturpeiden typpi. Jos luonnon olosuhteissa on havaittavissa eroja samalla maatumisasteella olevien mutasuoturpeiden ja rahkaturpeiden typen mineraloitumisessa, ne johtunevat muista tekijöistä kuin itse typpiyhdisteiden koostumuksesta. 